\title{
Alkali delignification and Bacillus sp. BMP01 hydrolysis of rice straw for enhancing biofuel yields
}

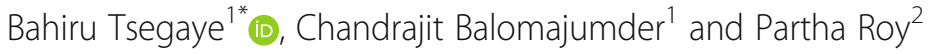

\begin{abstract}
Background: Lignocellulose biomass such as agricultural residues is increasingly important for biofuel production. Using agricultural residues like rice straw for biofuel production has dual purposes of utilizing the huge waste generated. The abundant availability and high polysaccharide contents are the main reason for biofuel production. However, the use is limited due to the reluctant nature of lignin in the biomass. Therefore, sodium hydroxide was used for solubilizing lignin and preserving the polysaccharides.

Results: About $71.29 \%$ of lignin (maximum amount of lignin) was removed after $7 \%$ sodium hydroxide $(\mathrm{NaOH})$ pretreatment followed by 3\% pretreatment (about 67.13\%). Also, maximum cellulose (about 71.33\%) was preserved after $7 \% \mathrm{NaOH}$ pretreatment. Results of reducing sugars obtained by spectrophotometric analysis (3,5-dinitrosalycilic acid method) of pretreated rice straw show about $88.27 \%$ conversion $(753 \mathrm{mg} / \mathrm{g})$ after the 13 th day of hydrolysis by bacteria isolated from a termite. FE-SEM, XRD, FTIR, and TGA analyses show a significant amount of lignin was removed which helps in releasing cellulose tangled in lignin.

Conclusion: Rice straw pretreatment at 7\% NaOH and hydrolysis by Bacillus sp. BMP01 achieved the release of a high yield of fermentable sugars that increased the yield of bioethanol. This study demonstrates the potential of alkali pretreatment coupled with microbial hydrolysis for efficient bioethanol production from agricultural residues like rice straw.
\end{abstract}

Keywords: Microbial hydrolysis, Rice straw, Bacillus sp. BMP01, Lignin removal, Cellulose, NaOH pretreatment

\section{Background}

Rice is one of the most common staple foods in the world in which half of the world population relies on it. Both in terms of consumption and growth, Asia alone accounts for about $90 \%$. From every 4 tons of rice grain produced, 4-6 tons of straw is obtained (Poornejad et al. 2013). Annually, about 550 million tons of straw and 110 million tons of husks are produced in Asia alone. Leaving rice straw on the soil causes emissions of methane to the atmosphere and delays the land preparation for the next cropping. Also, burning can cause air pollution and health problems (Binod et al. 2010). Therefore, alternative ways of disposing of the straw by reducing environmental risks are required. Besides this, rice straw

\footnotetext{
* Correspondence: bahlivej@gmail.com

'Department of Chemical Engineering, Indian Institute of Technology

Roorkee, Roorkee, Uttarakhand 247667, India

Full list of author information is available at the end of the article
}

can be used for alternate renewable energy resources through processes of chemical, physical, physicochemi$\mathrm{cal}$, or biological pretreatments. The abundance and high amount of polysaccharide content make it an ideal raw material for biofuel production. However, it is reluctant to enzymatic and microbial attacks making it difficult to use for biofuel production (Rastogi and Shrivastava 2017). Hence, pretreatment is required before hydrolysis and fermentation of polysaccharides to increase biofuel yield (Vandenbossche et al. 2014; Zhu et al. 2015; Fang et al. 2016).

Pretreatment is one of the most important steps to improve biodegradability by altering its composition and structure. It can also remove lignin and hemicellulose to a certain extent, which increases the porosity and concentration of amorphous cellulose (Ravindran and Jaiswal 2016; Gao et al. 2017; Sun and Cheng 2002; Tsegaye et al. 2019a; Tsegaye et al. 2019d). These are 
achieved by different mechanisms such as by applying high pressure and/or temperature, treatment with corrosive chemicals such as acids and alkali, use of enzyme and/or microorganisms, or the use of molecular disruption techniques such as ultrasound and plasma (Ravindran and Jaiswal 2016; Gao et al. 2017; Sun and Cheng 2002; Tsegaye et al. 2018).

Compared to other pretreatment methods, alkali pretreatments are the most effective ones because of its ability to increase cellulose accessibility and lignin removal capability (Ravindran and Jaiswal 2016; Zhang et al. 2012). The contents of lignin amount are a detrimental effect in alkali pretreatment process of lignocellulosic materials (Zhao et al. 2017). Alkali pretreatments work on the principle of saponification (de-esterification) of xylan-hemicellulose and lignin intermolecular crosslinking ester bonds. As much as the crosslinks (bonds) removed, lignocellulose porosity increased. Hemicellulose and lignin removal change the crystallinity index (gross) of the biomass which often contributes for increasing crystallinity index (gross) after pretreatments (Lai and Idris 2016; Wang et al. 2016; Tsegaye et al. 2019a; Tsegaye et al. 2019c). When $\mathrm{NaOH}$ is used as a pretreatment process, the internal surface area increased and crystallinity and degree of crystallinity are increased due to the swelling of lignocellulose material caused by $\mathrm{NaOH}$ that eventually leads to the removal of amorphous parts (Zhao et al. 2017).

Techniques, such as XRD, FE-SEM, FTIR, and thermogravimetric analysis (TGA), have been widely used to analyze the structural changes caused by alkali pretreatments of rice straw biomass. Employing FE-SEM provides the morphological and elemental composition changes. The crystallinity of the biomass is obtained by using XRD. FTIR gives information on functional changes where TGA gives thermal decomposition behavior of the biomass.

In this paper, the effect of various concentrations of $\mathrm{NaOH}$ treatments on the composition and microstructure of rice straws was studied using XRD, FTIR, FESEM, TGA, and spectrophotometric analysis. It was attempted to maximize delignification and biomass digestibility and to reduce the loss of sugars during pretreatment. The efficiency of bacterial hydrolysis of pretreated rice straw was also studied. Biofuel (bioethanol) production from the hydrolyzed rice straw samples was also investigated by employing carbon 5 and carbon 6 fermenting microorganisms (Zymomonas mobilis subsp. mobilis and Saccharomyces cerevisiae).

\section{Materials and method}

\section{Chemicals and straw preparation}

$\mathrm{NaOH}$, acetone, and sulfuric acid (analytical grade) were purchased from Himedia Laboratories Pvt. Ltd., Mumbai, India.
Rice straw was collected from the agricultural field around Roorkee, Uttarakhand, India. The straw was dried in an oven to moisture content (dry basis) of less than $10 \%$. Then, the straw was cut into pieces $(1-2 \mathrm{~mm})$ for $\mathrm{NaOH}$ treatments and ground to the size of $0.25 \mathrm{~mm}$ $(250 \mu \mathrm{m})$ for hydrolysis and analysis. After pretreatments, all the samples were kept in an airtight bag for further use and analysis.

\section{Compositional analysis}

The composition of raw and pretreated rice straw samples was analyzed according to the standard analytical procedures of the US National Renewable Energy Laboratory (NREL) (Sluiter et al. 2008). Ground rice straw samples were treated with $72 \%$ sulfuric acid for an hour and then diluted to 3\% sulfuric acid by adding 84 $\mathrm{ml}$ of distilled water and autoclaved for an hour at $121{ }^{\circ} \mathrm{C}$ and a pressure of $15 \mathrm{psi}$. Acid-soluble lignin was evaluated by UV spectrophotometry (Hach DR-5000) and acid-insoluble lignin by weight difference after oven drying and burning in a furnace $\left(575^{\circ} \mathrm{C}\right)$. The moisture content in the biomass was determined by convection oven procedure. Hexose and pentose sugars for $\mathrm{NaOH}-$ treated and untreated rice straw samples were analyzed by high-pressure liquid chromatography (HPLC) system equipped with an RI detector and Agilent Hi-Plex $\mathrm{H}$, $300 \times 7.7 \mathrm{~mm}$ column.

\section{Isolation of hydrolytic bacteria from a termite}

Termites were collected from the village around Roorkee, Uttarakhand, India. Hydrolytic bacteria have been isolated from termite gut and used for hydrolysis of pretreated rice straw. Details of the isolation and characterization of the isolates were mentioned in our previous work (Tsegaye et al. 2019b).

\section{$\mathrm{NaOH}$ pretreatments}

Various concentrations of $\mathrm{NaOH}$ were used for removing lignin and preserving polysaccharides. $\mathrm{NaOH}$ concentrations of $1,3,5,7$, and $10 \%$ at $80^{\circ} \mathrm{C}$ were used for pretreating rice straw for $4 \mathrm{~h}$. Pretreatments were carried out in a beaker $(1000 \mathrm{ml}$, borosil glass) containing 500 $\mathrm{ml}$ of sodium hydroxide solutions with a solid-to-liquid ratio of 1:10. The pretreated rice straws were washed by deionized water until the washings become clean and neutral to remove the alkali.

\section{Characterization}

\section{Scanning electron microscopy (SEM) analysis}

The morphology of rice straw (both raw and sodium hydroxide-treated) was analyzed by FE-SEM (field emission scanning electron microscope). The samples were coated with a gold layer using a Leica EM SCD050 sputter coater system before analysis. All samples were analyzed 
immediately after coating. Sample imaging was done by Carl Zeiss Ultra Plus FE-SEM operated with an acceleration voltage of $10 \mathrm{kV}$ and a working distance of 5-10 $\mathrm{mm}$. SEM micrographs of different areas and magnifications were taken for careful examination of sodium hydroxide effect on surface morphology and elemental composition.

\section{$X$-ray diffraction (XRD) analysis}

Effect of sodium hydroxide treatment on rice straw crystallinity was analyzed by X-ray diffraction using powdered X-ray diffractometer (Bruker D8-Advance) operated at $30 \mathrm{~mA}$ and $40 \mathrm{kV}$ with $\mathrm{Cu} / \mathrm{K}$ radiation. The sample was scanned at a scanning speed of $2^{\circ} / \mathrm{min}$ from $2 \theta=5^{\circ}$ to $95^{\circ}$ with a step size of $0.02^{\circ}$. Biomass crystallinity index (CrI) was determined by peak intensity method as the percentage of crystalline material in biomass (Segal et al. 1959).

$$
\mathrm{CrI}=\left(\frac{I_{002}-I_{\mathrm{am}}}{I_{002}}\right) \times 100
$$

where $I_{\mathrm{am}}$ is the intensity of the peak for the amorphous portion at $2 \theta=18^{\circ}$ and $I_{002}$ is the maximum intensity at $2 \theta=22$.

The Scherer equation was used to calculate the apparent crystallite size $(L)$ (Scherrer 1918).

$$
L=K \lambda / \beta \operatorname{Cos} \theta
$$

where $L=$ apparent crystalline size, $k=$ dimensionless shape factor (0.94), $\lambda=\mathrm{X}$-ray wavelength (0.1542), $\beta=$ line bordering in radian, and $\theta=$ Bragg angle.

The degree of crystallinity was calculated based on the area under crystalline peaks and non-crystalline region using the following equation:

$$
X_{c}=\left(\frac{F_{c}}{F_{a}+F_{c}}\right) \times 100
$$

where $X_{c}$ is a degree of crystallinity, $F_{c}$ is the area of crystalline, and $F_{a}$ is the non-crystalline regions.

\section{Fourier transform infrared spectroscopy (FTIR) analysis}

Fourier transform infrared spectroscopy was used to analyze the change in functional groups caused by sodium hydroxide treatments. Sodium hydroxide-treated and untreated (raw) rice straw spectra were generated by using FTIR-Thermo Scientific Nicolet 6700 spectrometer (FTIR, Thermo Nicolet 6700, USA). FT-IR spectra were obtained within the scanning range of $4000-500 \mathrm{~cm}^{-1}$ with a detector at $4 \mathrm{~cm}^{-1}$ resolution and 32 scans per sample.

\section{Thermogravimetric analysis (TGA)}

Thermal stability and decomposition temperature of the main rice straw constituents were analyzed for each sodium hydroxide-treated rice straw by using the thermogravimetric analyzer. TGA measurements were taken using a thermogravimetric analyzer (TGA) (SII 6300 EXSTAR) operating in a nitrogen environment. Samples for each measurement were maintained at $10.0 \pm 0.5 \mathrm{mg}$, and scans were performed from 30 to $800^{\circ} \mathrm{C}$ at a rate of $10^{\circ} \mathrm{C} / \mathrm{min}$.

\section{Hydrolysis of pretreated rice straw}

Hydrolysis of sodium hydroxide pretreated rice straw was done in a $250-\mathrm{ml}$ round bottom flask. The efficiency of hydrolysis was studied by measuring reducing sugar produced within 2-day intervals using 3,5-initrosalycilic acid method (Miller 1959). The hydrolysis was done in an orbital shaker incubator (Metrex, MO-250, India) at $30{ }^{\circ} \mathrm{C}$ and $120 \mathrm{rpm}$.

\section{Fermentation}

Zymomonas mobilis subsp. mobilis (MTCC 91) and Saccharomyces cerevisiae (MTCC 170) were obtained from the Microbial Type Culture Collection and Gene Bank, Chandigarh, India, and used for ethanol fermentation. The microorganisms were grown for $12 \mathrm{~h}$ at $30^{\circ} \mathrm{C}$ and transferred to fermentation media. The hydrolyzed rice straw samples were sterilized at $121^{\circ} \mathrm{C}$ for $15 \mathrm{~min}$. The sterilized medium was inoculated with $2.5 \times 10^{7}$ yeast cell per milliliter and $3.15 \times 10^{5}$ bacteria cell per milliliter. The ethanol fermentation was performed in a 250-ml flask incubated at $30^{\circ} \mathrm{C}$ for $96 \mathrm{~h}$ in a shaker incubator $(120 \mathrm{rpm})$. The supernatants were centrifuged at $7000 \mathrm{rpm}$ for $5 \mathrm{~min}$. The ethanol content was analyzed by HPLC equipped with an RI detector. Ethanol yield was calculated to determine the efficiency of the fermentation process.

$$
\text { Ethanol yield } \%=\left(\frac{E \times V}{m \times 0.511}\right) \times 100
$$

where $E$ is the concentration of ethanol produced during fermentation (milligrams per milliliter), $V$ is the total volume of the medium (milliliters), $m$ is the initial dry weight of glucose at the start of fermentation (milligrams), and 0.511 is the conversion factor for glucose to ethanol during the biochemical process.

\section{Results}

Effect of pretreatment on rice straw composition

The chemical composition of raw and sodium hydroxide-treated rice straws are presented in Table 1 . The effect of different concentrations of sodium hydroxide treatments is described by comparing it with raw/ 
Table 1 Proximate composition of rice straw treated with $\mathrm{NaOH}$ and untreated straw

\begin{tabular}{|c|c|c|c|c|}
\hline \multirow{2}{*}{$\begin{array}{l}\text { Treatment } \\
\text { with } \mathrm{NaOH}\end{array}$} & \multicolumn{4}{|c|}{ Compositional analysis } \\
\hline & $\begin{array}{l}\text { Cellulose } \\
(\%)\end{array}$ & $\begin{array}{l}\text { Hemicellulose } \\
(\%)\end{array}$ & $\begin{array}{l}\text { Lignin } \\
(\%)\end{array}$ & $\begin{array}{l}\text { Moisture } \\
(\%)\end{array}$ \\
\hline $\begin{array}{l}\text { Before } \\
\text { treatment }\end{array}$ & 38.02 & 18.30 & 21.60 & 8.46 \\
\hline $1 \%$ & 51.64 & 12.63 & 11.78 & 7.83 \\
\hline $3 \%$ & 70.56 & 14.78 & 7.10 & 7.18 \\
\hline $5 \%$ & 67.87 & 12.50 & 9.12 & 7.33 \\
\hline $7 \%$ & 71.33 & 13.48 & 6.20 & 7.24 \\
\hline $10 \%$ & 68.47 & 8.53 & 8.86 & 9.46 \\
\hline
\end{tabular}

untreated rice straw. The effects of different concentrations of $\mathrm{NaOH}$ on the three main rice straw compositions are given in Fig. 1.

\section{Characterization of pretreated rice straw Scanning electron microscopy analysis (SEM)}

The effect of different concentrations of $\mathrm{NaOH}$ treatments on surface morphology and the microstructure of rice straw were characterized by scanning electron microscopy (SEM). Figure 2 shows an electron micrograph of rice straw treated with different concentrations of $\mathrm{NaOH}$ and untreated (raw) straw. Changes on the surface microstructure and morphology of rice straw were observed following $\mathrm{NaOH}$ pretreatments.

\section{$X$-ray diffraction (XRD) analysis}

The XRD pattern of $\mathrm{NaOH}$ pretreated and untreated rice straw samples are given in Table 2 .

Figure 3 a presents the X-ray diffraction patterns of $1,3,5,7$, and $10 \% \mathrm{NaOH}$-treated and untreated rice straw. As seen from the plot, all treated samples showed little increments in peak height relative to untreated rice straw. The difference in the XRD

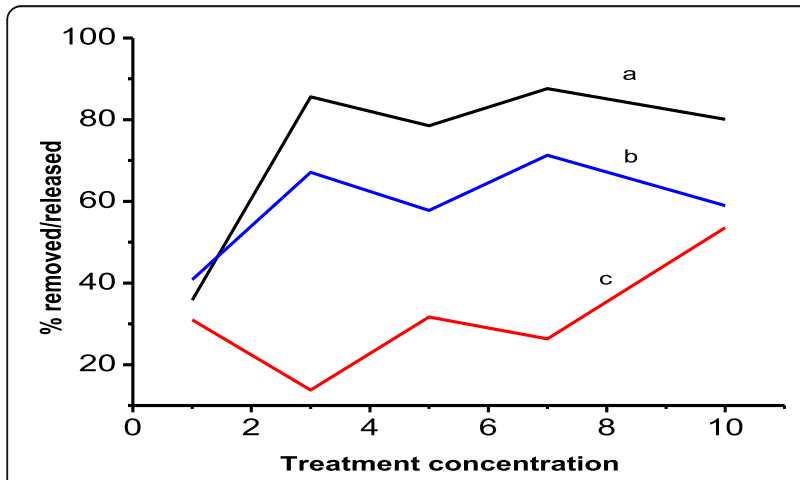

Fig. 1 Effect of different concentration of $\mathrm{NaOH}$. a Percentage of cellulose increased, $\mathbf{b}$ percentage of lignin removed, and $\mathbf{c}$ percentage of hemicellulose removed after 1, 3, 5, 7, and 10\% $\mathrm{NaOH}$ treatments profile of the untreated and treated rice straw indicates that different concentrations of $\mathrm{NaOH}$ solution applied to rice straw had significant changes in the crystalline nature of the straw used.

\section{Fourier transform infrared spectroscopy (FTIR) analysis}

Changes induced by different concentrations of sodium hydroxide pretreatment on rice straw were investigated by analyzing the appearance and/or disappearance and decrease and/or increase of absorption bands of functional groups that are assigned to lignin, cellulose, and hemicellulose (He et al. 2008; Gao et al. 2017). Figure 4 shows FTIR spectra of untreated and sodium hydroxide pretreated $(1,3,5,7$, and $10 \%)$ rice straw. The spectrum of both untreated and pretreated showed a little similarity of absorbance intensity tendency with weak and strong absorbance intensities depending upon the concentration of sodium hydroxide used. Major IR spectra appeared and disappeared during treatments of rice straw that are related to compounds assigned for hemicellulose, cellulose, and lignin are given in Table 3 (Bilba and Alex 1996; Yang et al. 2006; Zhao et al. 2016; Phitsuwan et al. 2016; Wang et al. 2016).

\section{Thermogravimetric analysis (TGA)}

Figure $3 \mathrm{~b}$ shows the derivative of weight loss with respect to the temperature obtained from TGA analysis for alkali-treated and hydrolyzed rice straw. The rate of removal of cellulose and hemicellulose is given in Table 4 for all treatments considered.

\section{Microbial hydrolysis and fermentation of pretreated rice straw}

All pretreated straws were subjected to hydrolysis using bacteria isolated from termite gut. The bacterial isolates (Bacillus sp. BMP01) were used for simultaneous hydrolysis of hemicellulose and cellulose obtained after sodium hydroxide pretreatment. The concentration of reducing sugar obtained after bacterial hydrolysis for all pretreatments are given in Table 5. Figure 5 describes the percentage of sugar released after microbial hydrolysis for all $\mathrm{NaOH}$ pretreated rice straw.

\section{Discussion}

Effect of pretreatment on rice straw composition

From Table 1, we observe that the percentage of cellulose increased from 38.02 to $71.33 \%$ after treating with $7 \% \mathrm{NaOH}$ that is the maximum amount of cellulose obtained. Hemicellulose was also solubilized in $\mathrm{NaOH}$ solution and decreased from 18.3 to $8.53 \%$. Treatment with $3 \%$ and $7 \% \mathrm{NaOH}$ releases maximum cellulose and solubilizes minimum amount of hemicellulose. The amount of lignin was decreased significantly from 21.6 to $6.2 \%$. 

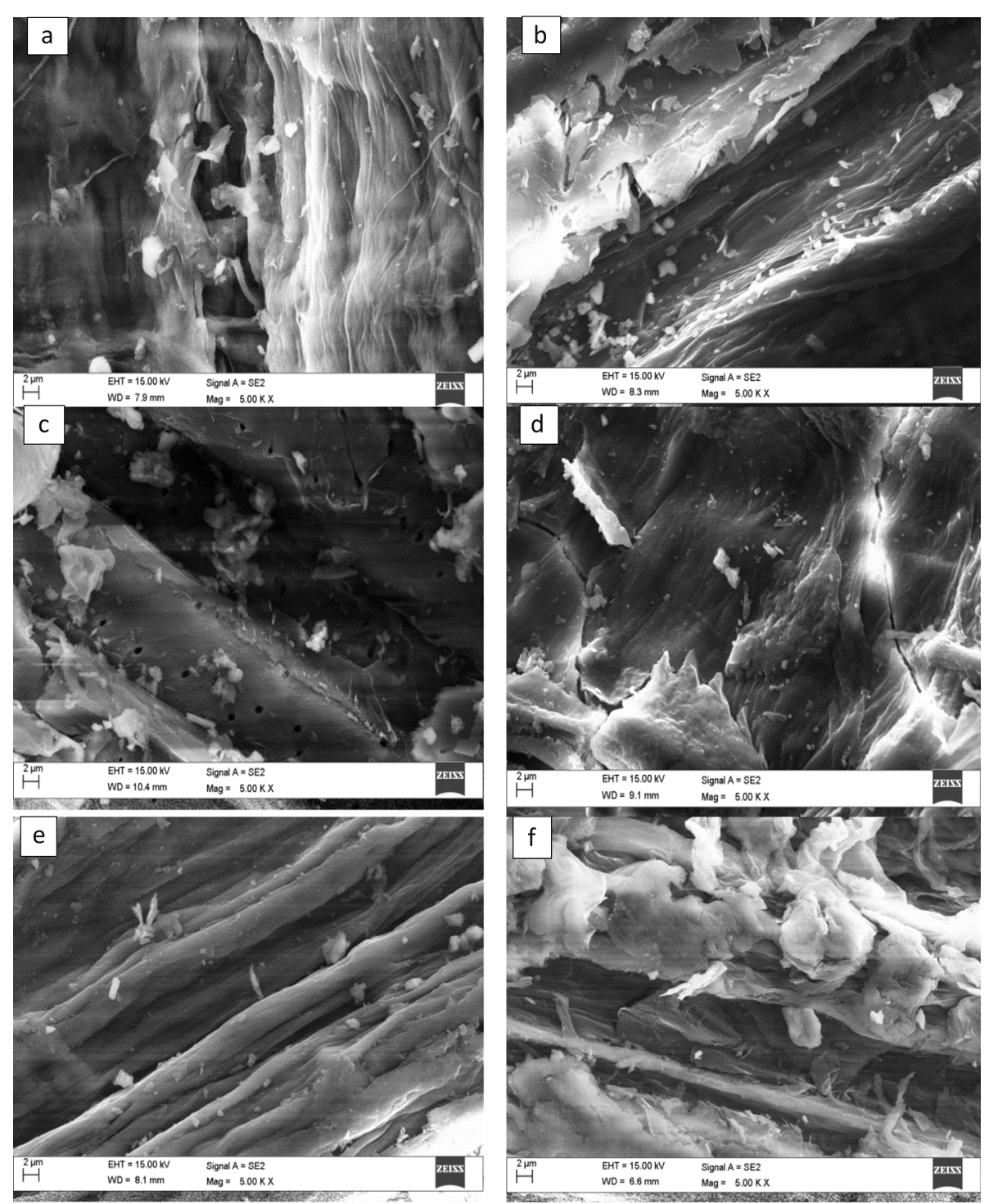

Fig. 2 Electron micrograph of rice straw particles at $\times 5000$ magnification. a Untreated (raw). b $1 \% \mathrm{NaOH}$ treated. c $3 \% \mathrm{NaOH}$ treated. d $5 \%$ $\mathrm{NaOH}$ treated. e $7 \% \mathrm{NaOH}$ treated. f $10 \% \mathrm{NaOH}$ treated

From Fig. 1, we observe that the amount of lignin and hemicellulose decreased and the amount of cellulose is increased. Maximum removal of lignin was observed at

Table 2 XRD profile of $\mathrm{NaOH}$ treated rice straw and untreated straw

\begin{tabular}{llll}
\hline $\begin{array}{l}\text { Treatment } \\
\text { concentration }\end{array}$ & $\begin{array}{l}\text { Crystallinity } \\
\text { index (Cri \%) }\end{array}$ & $\begin{array}{l}\text { Degree of } \\
\text { crystallinity (Xc \%) }\end{array}$ & $\begin{array}{l}\text { Crystalline } \\
\text { size (nm) }\end{array}$ \\
\hline Untreated & 41.59 & 58.64 & 2.45 \\
$1 \%$ & 50.32 & 63.23 & 2.84 \\
$3 \%$ & 56.93 & 66.43 & 6.25 \\
$5 \%$ & 51.73 & 64.88 & 5.21 \\
$7 \%$ & 62.71 & 68.67 & 7.45 \\
$10 \%$ & 56.18 & 63.90 & 4.47 \\
\hline
\end{tabular}

$7 \% \mathrm{NaOH}$ treatment with $71.29 \%$ lignin removal. $67.13 \%$ lignin removal was also observed at $3 \%$ treatment. Low amount of hemicelluloses $13.77 \%$ and $26.34 \%$ were also solubilized at $3 \%$ and $7 \%$ treatments, respectively. Compared to raw rice straw, significant change in carbohydrate and lignin composition was observed in all treatments. The increment in cellulose composition and reduction in lignin and hemicellulose amount was mainly attributed by the saponification reaction between $\mathrm{NaOH}$ and intermolecular ester linkage that produces active carboxyl group that cleaves lignin and hemicellulose linkages. This causes the destruction of biomass component matrix (cellulose-hemicellulose-lignin) (Lai and Idris 2016; Wang et al. 2016). In this study, we found that $3 \%$ and $7 \% \mathrm{NaOH}$ treatments are more 


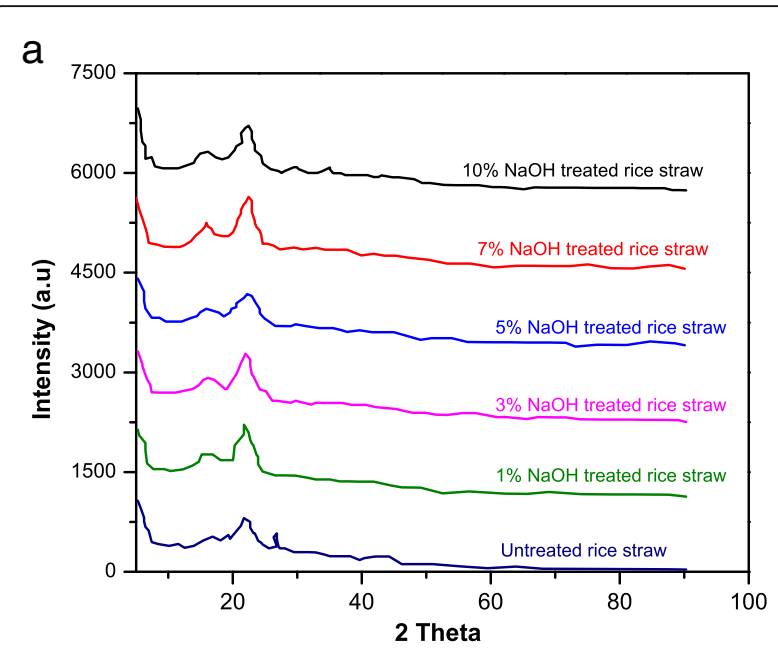

b

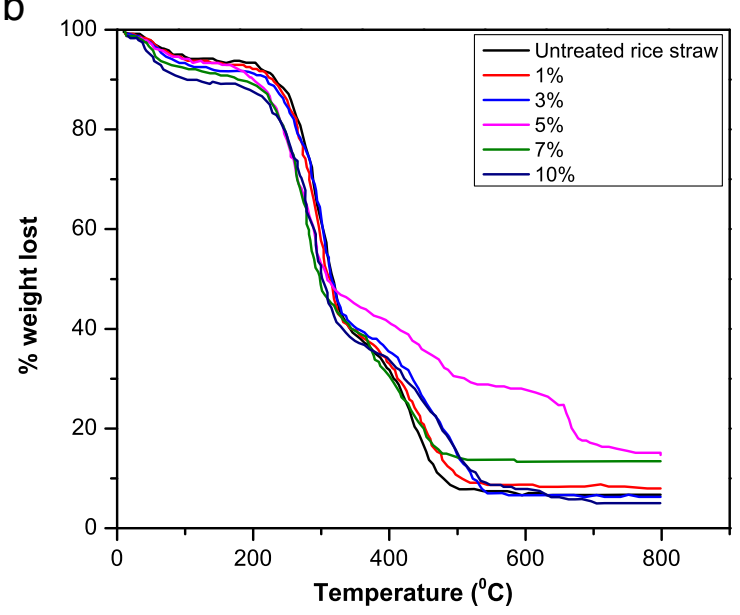

Fig. 3 a XRD profile of $\mathrm{NaOH}$ pretreated and raw rice straw. $\mathbf{b}$ TGA profiles of raw rice straw and $\mathrm{NaOH}$ pretreated rice straw

effective for lignin removal and to release the maximum amount of cellulose.

\section{Characterization of pretreated rice straw Scanning electron microscopy analysis (SEM) analysis}

The raw rice straw (untreated) showed a rigid and compact surface structure whereas there is an appreciable surface modification on the treated ones. Pores and cracks were observed in $3 \% \mathrm{NaOH}$ treatments (Fig. 2c) whereas cracks were observed on $1 \%$ and $5 \% \mathrm{NaOH}$ treatments (Fig. 2b, d). Scaling and more layering as well as splitting of fibers and abrasion were observed on $7 \%$ $\mathrm{NaOH}$ treatment (Fig. 2e) whereas irregular and rough structure were observed in all treatments. Relative to raw straw, noticeable changes were observed on the morphology and surface structure of all treated rice straw. The possible reason for this may be due to the breaking of lignin-xylan bond caused by $\mathrm{NaOH}$ activity, thus increasing the porosity of rice straw (Ravindran and
Jaiswal 2016; Gao et al. 2017). McMillan demonstrated that lignin-hemicellulose-cellulose matrix is cleaved and destroyed by excited carboxyl groups produced by saponification of ester linkage on xylan backbone facilitating in hemicellulose and lignin removal and causing hydrogen bonds disruption in the cellulose (McMillan 1994).

\section{$X$-ray diffraction (XRD) analysis}

Crystallinity index increased from 41.59 (untreated) to 62.71 (7\% treated) and crystalline size from $2.45 \mathrm{~nm}$ (untreated) to $7.45 \mathrm{~nm}$ ( $7 \%$ treated). The maximum size of the crystalline structure, the high degree of crystallinity, and the maximum crystallinity index were observed after 7\% treatment. Maximum peak heights were seen for 3 and $7 \% \mathrm{NaOH}$-treated rice straws followed by $10 \%$ treatment. One and 5\% treatments showed minimum peak heights (Fig. 3a and Table 2). Relative to treated rice straw, much less peak height was observed for untreated straw due to hemicellulose fraction and lignin interference (Kahar et al. 2013). The increments in peak intensities of straws after treatments with different sodium hydroxide solution $(1,3,5,7$, and $10 \%)$ indicate that there was enhanced solubility of lignin and hemicellulose removal ( $\mathrm{Pu}$ et al. 2013; Wang et al. 2016; Jin et al. 2016). Hydrogen bond rapture within cellulose crystalline regions which causes hydrolysis of glycosidic linkage and ester bond was possibly the main reason attributed for increments in peak intensities of rice straw after sodium hydroxide pretreatments (Foston and Ragauskas 2010; He et al. 2008; Gao et al. 2017). From Table 2, we observe that the degree of crystallinity and crystallinity index of rice straw was increased after sodium hydroxide pretreatments indicating lignin and hemicellulose were solubilized and cellulose were released (Mansfield et al. 1999). These results are online with data obtained by SEM analysis and proximate analysis.

\section{Fourier transform infrared spectroscopy (FTIR) analysis}

Major changes in functional groups of rice straw components (hemicellulose, cellulose, and lignin) were observed. Strong wide band between 3100 and 3500 $\mathrm{cm}^{-1}$ has assigned for $\mathrm{O}-\mathrm{H}$ stretching vibration of lignin. The IR spectrum at $3409.26 \mathrm{~cm}^{-1}$ in raw rice straw is caused by the presence of phenolic and alcoholic hydroxyl group. This wavenumber shifts to 3410.31 $\mathrm{cm}^{-1}, 3429.48 \mathrm{~cm}^{-1}$, and $3425.09 \mathrm{~cm}^{-1}$ for 3,5 , and $7 \%$ sodium hydroxide-treated rice straws due to demethylation of $\mathrm{O}-\mathrm{CH}_{3}$ bond in the methoxyl group, which contributes to the formation of new $\mathrm{O}-\mathrm{H}$ group by replacing $\mathrm{CH}_{3}$ (Durie et al. 1960). The aromatic ring at $2360.43 \mathrm{~cm}^{-1}$ and $2330.99 \mathrm{~cm}^{-1}$ disappeared after 3 and $7 \%$ treatments. Bands of hemicellulose for $\mathrm{C}-\mathrm{C}$ 


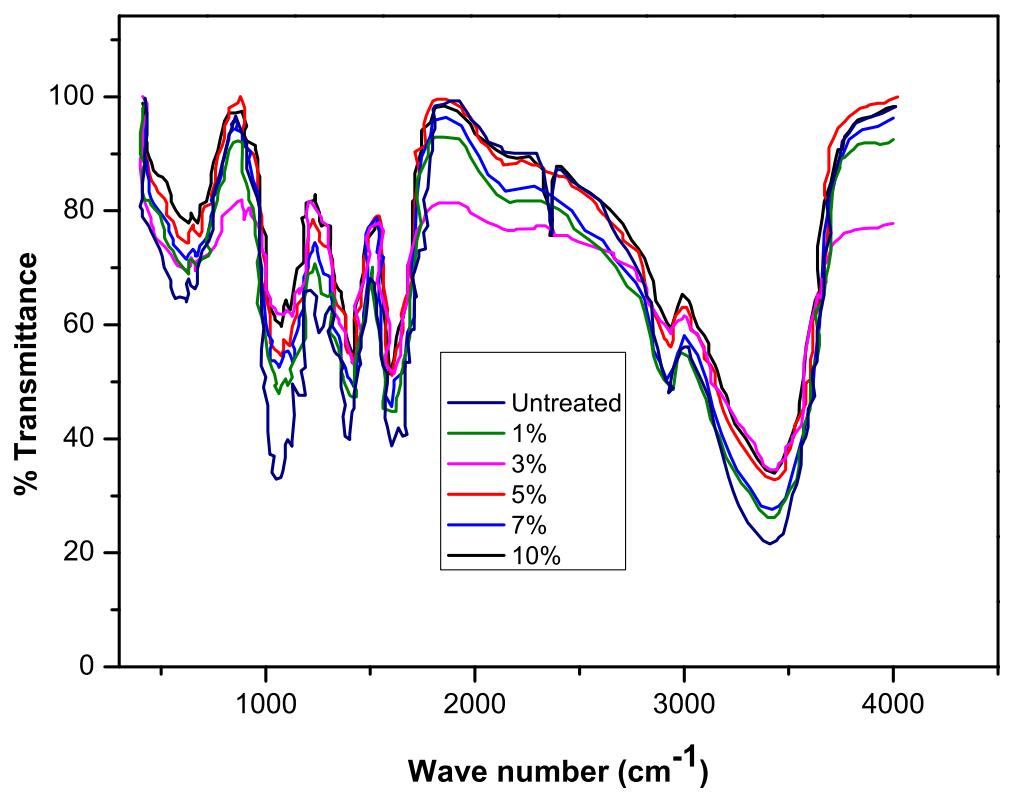

Fig. 4 FTIR spectra of native and $\mathrm{NaOH}$ pretreated rice straw

stretching at 467.70 disappeared and new bands of the carbonyl stretching appear at 1639.5, 1621.59, 1636.30, and 1648.08 for $3,5,7$, and $10 \%$ sodium hydroxidetreated rice straw, respectively. Between the regions of $850-1250 \mathrm{~cm}^{-1}$, cellulose characteristic bands were detected. The appearance of new cellulose bands assigned for C-O stretching was also observed at 1206.54, 1200.65 , and 1203.06 for 3,7 , and $10 \%$ treated straw, respectively. Three and 7\% $\mathrm{NaOH}$-treated rice straws show the best lignin removal when compared to other treatments used and 5\% and 10\% show more hemicellulose solubility. The solubility of lignin and hemicellulose released cellulose bounded to them resulting in an increase in cellulose composition after treatment.

\section{Thermogravimetric analysis (TGA)}

Hemicellulose starts to decompose at $180^{\circ} \mathrm{C}$ and goes up to $330^{\circ} \mathrm{C}$ whereas cellulose degrades at a higher

Table 3 Major adsorption bands appeared and/or disappeared after $\mathrm{NaOH}$ treatments

\begin{tabular}{|c|c|c|c|c|c|c|c|}
\hline \multirow[t]{2}{*}{ Assignment of bands } & \multirow[t]{2}{*}{ Related structure } & \multirow[t]{2}{*}{$\begin{array}{l}\text { Adsorption band } \\
\text { of raw RS }\end{array}$} & \multicolumn{5}{|c|}{$\begin{array}{l}\text { Adsorption band appeared or disappeared due to } \\
\mathrm{NaOH} \text { pretreatment of rice straw }\end{array}$} \\
\hline & & & $1 \%$ & $3 \%$ & $5 \%$ & $7 \%$ & $10 \%$ \\
\hline $\mathrm{O}-\mathrm{H}$ stretching & Lignin & 3409.26 & 3409.97 & 3410.31 & 3429.48 & 3425.09 & 3407.36 \\
\hline $\mathrm{C}-\mathrm{H}$ stretching & Lignin & 2854.95 & 2852.00 & & 2854.95 & 2849.06 & \\
\hline $\mathrm{C} \equiv \mathrm{C}$ stretching & aromatic rings & 2360.43 & 2360.43 & & 2363.37 & & 2366.31 \\
\hline $\mathrm{C} \equiv \mathrm{C}$ stretching & aromatic rings & 2330.99 & 2336.88 & & 2339.82 & & 2333.93 \\
\hline Carbonyl stretching conjugate with aromatic rings & Cellulose & & & 1639.25 & 1621.59 & 1636.30 & 1648.08 \\
\hline Aromatic $\mathrm{C}-\mathrm{O}$ stretch & Lignin & & 1505.84 & & & & \\
\hline $\mathrm{C}-\mathrm{O}$ stretching & Cellulose & 1405.19 & & 1406.11 & 1405.18 & 1405.50 & 1406.34 \\
\hline $\mathrm{C}-\mathrm{H}$ symmetric and asymmetric deformation & Cellulose & 1380.21 & & 1383.16 & 1383.16 & 1380.21 & 1380.21 \\
\hline $\mathrm{C}-\mathrm{O}$ stretching & Cellulose & 1333.12 & 1333.12 & 1330.17 & 1336.06 & 1336.06 & \\
\hline Acetylated hemicellulos & Hemicellulose & 1256.58 & 1262.47 & 1268.16 & 1265.41 & 1265.41 & \\
\hline Weak C-O stretching & Cellulose & & 1206.54 & & 1200.65 & 1203.06 & \\
\hline Glycosidic linkage & Hemicellulose & & & 1197.71 & & & 1197.71 \\
\hline $\mathrm{C}-\mathrm{O}$ stretching & Cellulose hemicellulose & & 832.71 & & 835.65 & 835.65 & 841.54 \\
\hline $\mathrm{C}-\mathrm{H}$ bending & Hemicellulose & 770.89 & & 709.08 & 712.02 & & \\
\hline C-C stretching & Hemicellulose & 467.70 & 470.65 & & & & 520.69 \\
\hline
\end{tabular}


Table 4 Rate of weight loss of rice straw

\begin{tabular}{|c|c|c|c|c|}
\hline Treatment with $\mathrm{NaOH}(\%)$ & Affected composition & Temperature range $(\mathrm{C})$ & Rate of weight removal (mg/min) & $\%$ removal \\
\hline \multirow[t]{3}{*}{ Untreated } & Hemicellulose & $180-300$ & 0.78 & 45.11 \\
\hline & Cellulose & $300-600$ & 0.27 & 30.34 \\
\hline & Lignin & $200-700$ & & \\
\hline \multirow[t]{3}{*}{$1 \%$ treated } & Hemicellulose & $200-330$ & 0.79 & 49.55 \\
\hline & Cellulose & $340-550$ & 0.24 & 24.9 \\
\hline & Lignin & $200-650$ & & \\
\hline \multirow[t]{3}{*}{$3 \%$ treated } & Hemicellulose & $200-330$ & 0.84 & 50.54 \\
\hline & Cellulose & $340-520$ & 0.32 & 32.6 \\
\hline & Lignin & $200-600$ & & \\
\hline \multirow[t]{3}{*}{$5 \%$ treated } & Hemicellulose & $200-340$ & 0.75 & 52.55 \\
\hline & Cellulose & $350-520$ & 0.38 & 30.6 \\
\hline & Lignin & $200-600$ & & \\
\hline \multirow[t]{3}{*}{$7 \%$ treated } & Hemicellulose & $200-330$ & 0.83 & 48.39 \\
\hline & Cellulose & $340-550$ & 0.38 & 32.3 \\
\hline & Lignin & $200-600$ & & \\
\hline \multirow[t]{3}{*}{$10 \%$ treated } & Hemicellulose & $200-320$ & 0.61 & 43.76 \\
\hline & Cellulose & $330-600$ & 0.22 & 19.72 \\
\hline & Lignin & $200-600$ & & \\
\hline
\end{tabular}

temperature between 300 and $400{ }^{\circ} \mathrm{C}$. Lignin degrades slowly between 200 and $600{ }^{\circ} \mathrm{C}$ (Kumabe et al. 2007). From Fig. $3 \mathrm{~b}$, we observe that the rate of weight loss is very high (about $80 \%$ ) between $200-500{ }^{\circ} \mathrm{C}$ for all treatments considered. Lignin loses slowly within $200-600^{\circ} \mathrm{C}$ but hemicellulose was lost in a much faster rate than the others were. From Table 4, we observe that the range of temperature for lignin removal was reduced indicating lignin was solubilized in the pretreatment process. The maximum rate of weight loss of cellulose was observed for $3 \%$ and $7 \%$ pretreated rice straws indicating cellulose was released from the hemicellulose-lignin matrix.

Table 5 Reducing sugar obtained after bacterial hydrolysis for treated rice straw

\begin{tabular}{llllll}
\hline $\begin{array}{l}\text { Treatment } \\
\text { time (days) }\end{array}$ & \multicolumn{4}{l}{$\begin{array}{l}\text { Reducing sugar concentration at different treatments } \\
(\mathrm{g} / 100 \mathrm{ml})\end{array}$} \\
\cline { 2 - 6 } & $1 \%$ & $3 \%$ & $5 \%$ & $7 \%$ & $10 \%$ \\
\hline 1 & 0.152 & 0.081 & 0.116 & 0.081 & 0.128 \\
3 & 0.175 & 0.34 & 0.151 & 0.128 & 0.14 \\
5 & 0.199 & 0.364 & 0.199 & 0.187 & 0.199 \\
7 & 0.258 & 0.411 & 0.305 & 0.281 & 0.258 \\
9 & 0.258 & 0.564 & 0.423 & 0.399 & 0.364 \\
11 & 0.293 & 0.6 & 0.517 & 0.529 & 0.47 \\
13 & 0.387 & 0.753 & 0.552 & 0.658 & 0.566 \\
15 & 0.423 & 0.742 & 0.627 & 0.741 & 0.582 \\
17 & 0.411 & 0.741 & 0.627 & 0.735 & 0.576 \\
\hline
\end{tabular}

\section{Microbial hydrolysis and fermentation of pretreated rice} straw

At the start, minimum sugar was released in all pretreated straw since the bacteria were adapting and preparing enzymes for hydrolysis. We observe that the amount of reducing sugar obtained increases with hydrolysis time and maximum sugar was released at the 13th and 15th day for 3 and $7 \%$ treated straws, respectively. The maximum sugar released from the polysaccharide was $0.753 \mathrm{~g} / 100 \mathrm{ml}$ for $3 \%$ pretreated rice straw and $0.741 \mathrm{~g} / 100 \mathrm{ml}$ for $7 \%$ pretreated rice straw. It was observed that $88.27 \%$ of sugar

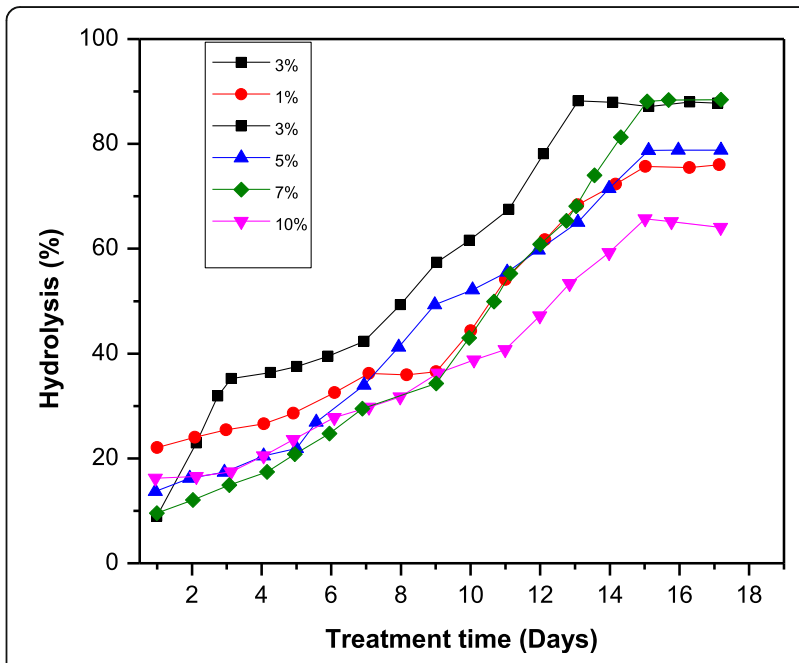

Fig. 5 Percentage of sugar released after microbial hydrolysis for $1,3,5,7$, and $10 \% \mathrm{NaOH}$ pretreated rice straw 
was released on the 13th day from $3 \%$ pretreated rice straw and $88.40 \%$ released from $7 \%$ pretreated rice straw after the 15th day of hydrolysis. This is the maximum percentage released after treating the pretreated rice straw simultaneously with xylan and cellulose-degrading bacteria (Bacillus sp. BMP01). Removal of lignin by alkali facilitates the enzymatic and microbial hydrolysis of rice straw (Azizi-shotorkhoft et al. 2016; Yan et al. 2015). This result reveals that alkali pretreatment enhanced the release of reducing sugars, which were initially bonded to lignin in the biomass matrix.

After $96 \mathrm{~h}$ fermentation, the hydrolyzed rice straw sample resulted in $88.62 \%$ ethanol yield. The result clearly indicates the advantage of using alkali pretreatment along with microbial hydrolysis. This result was quite impressive compared to other reported works in literature (Agblevor et al. 2003). The use of xylose-fermenting microbe increased the ethanol yield. Hence, using microbial consortium utilizing glucose and xylose was effective in converting all the available fermentable sugars that enhanced ethanol production.

\section{Conclusions}

This study shows sodium hydroxide has a significant effect in removing lignin, which opens the biomass structure for microbial or enzymatic hydrolysis. The combination of sodium hydroxide pretreatment with microbial hydrolysis has significant capacity for biofuel production. Pretreatment in 3\% and 7\% sodium hydroxide concentration at $80^{\circ} \mathrm{C}$ were effective in removing $67.13 \%$ and $71.29 \%$ of lignin, respectively. These pretreatments were also effective in solubilizing lower amount of hemicellulose compared to other pretreatments. $70.56 \%$ and $71.33 \%$ of cellulose were preserved after $3 \%$ and $7 \%$ pretreatments, respectively, due to solubilization of high amount of lignin and hemicellulose. $88.27 \%$ and $88.40 \%$ of all the polysaccharides were converted to glucose and xylose after subjecting to microbial hydrolysis. Microbial sources from a termite showed great potential to replace commercial enzymes. Generally, the study revealed the enhancement of bioethanol production by coupling alkali pretreatment with microbial hydrolysis and fermentation of carbon 5 and carbon 6 sugars.

\footnotetext{
Abbreviations

Crl: Crystallinity index; FE-SEM: Field emission scanning electron microscopy analysis; FTIR: Fourier transform infrared spectroscopy; HPLC: High-pressure liquid chromatography; L: Crystalline length; MTCC: Microbial Type Culture Collection; $\mathrm{NaOH}$ : Sodium hydroxide; NREL: National Renewable Energy Laboratory; RI detector: Refractive index detector; TGA: Thermogravimetric analysis; UV spectrophotometry: Ultraviolet-visible spectrophotometry; $X_{c}$ : Degree of crystallinity; XRD: X-ray diffractometer
}

\section{Authors' contributions}

BT initiated the idea, performed the experiments, analyzed the data, and drafted the manuscript. CBM and PR participated in analyzing the data, design, and coordination and refined and edited the final manuscript. All authors read and approved the final manuscript.

\section{Funding}

This research did not receive any specific grant from funding agencies in the public, commercial, or not-for-profit sectors.

\section{Availability of data and materials}

Data sharing is not applicable to this article as no datasets were generated or analyzed during the current study.

Ethics approval and consent to participate

Not applicable

\section{Consent for publication}

All the participant researchers are consent for publication.

\section{Competing interests}

The authors declare that they have no competing interests.

\section{Author details}

${ }^{1}$ Department of Chemical Engineering, Indian Institute of Technology Roorkee, Roorkee, Uttarakhand 247667, India. ²Department of Biotechnology, Indian Institute of Technology Roorkee, Roorkee, Uttarakhand 247667, India.

Received: 19 March 2019 Accepted: 6 August 2019

Published online: 22 August 2019

\section{References}

Agblevor FA, Batz S, Trumbo J (2003) Composition and ethanol production potential of cotton gin residues. Appl Biochem Biotechnol 105(1-3):219-230

Azizi-shotorkhoft A, Mohammadabadi T, Motamedi H, Chaji M (2016) Isolation and identification of termite gut symbiotic bacteria with lignocellulosedegrading potential, and their effects on the nutritive value for ruminants of some by-products. Anim Feed Sci Technol 221:234-242. https://doi.org/10.1 016/j.anifeedsci.2016.04.016

Bilba K, Alex O (1996) Fourier transform infrared spectroscopic study of thermal degradation of sugar cane bagasse. J Anal Appl Pyrolysis 2370:61-73

Binod P, Sindhu R, Singhania RR, Vikram S, Devi L, Nagalakshmi S, Kurien N et al (2010) Bioethanol production from rice straw : an overview. Bioresour Technol 101:4767-4774

Durie RA, Lynch BM, Sternhell S (1960) Comparative studies of brown coal and lignin. I. Infrared spectra. Aust J Chem 13:156-168

Fang H, Zhao C, Kong Q, Chen N (2016) Comprehensive utilization and conversion of lignocellulosic biomass for the production of long-chain a , w -dicarboxylic acids. Energy. 116:177-189. https://doi.org/10.1016/j.energy.2 016.09.110

Foston M, Ragauskas AJ (2010) Changes in lignocellulosic supramolecular and ultrastructure during dilute acid pretreatment of Populus and switchgrass. Biomass Bioenergy 34:1885-1895. https://doi.org/10.1016/j.biombioe.2010.07.023

Gao C, Xiao W, Ji G, Zhang Y, Cao Y, Han L (2017) Regularity and mechanism of wheat straw properties change in ball milling process at cellular scale. Bioresour Technol 241:214-219. https://doi.org/10.1016/j.biortech.2017.04.115

He Y, Pang Y, Liu Y, Li X, Wang K (2008) Physicochemical characterization of rice straw pretreated with sodium hydroxide in the solid state for enhancing biogas production. Energy Fuel 22:2775-2781. https://doi.org/10.1021/ ef8000967

Jin S, Zhang G, Zhang P, Li F, Wang S, Fan S, Zhou S (2016) Microwave assisted alkaline pretreatment to enhance enzymatic saccharification of catalpa sawdust. Bioresour Technol 221:26-30. https://doi.org/10.1016/j.biortech.2016. 09.033

Kahar P, Taku K, Tanaka S (2013) Multiple effects of swelling by sodium bicarbonate after delignification on enzymatic saccharification of rice straw J Biosci Bioeng 116:725-733. https://doi.org/10.1016/j.jbiosc.2013.05.036

Kumabe K, Hanaoka T, Fujimoto S, Minowa T, Sakanishi K (2007) Co-gasification of woody biomass and coal with air and steam. Fuel. 86:684-689. https://doi. org/10.1016/j.fuel.2006.08.026 
Lai LW, Idris A (2016) Comparison of steam-alkali-chemical and microwave-alkali pretreatment for enhancing the enzymatic saccharification of oil palm trunk. Renew Energy 99:738-746. https://doi.org/10.1016/j.renene.2016.07.059

Mansfield SD, Mooney C, Saddler JN (1999) Substrate and enzyme characteristics that limit cellulose hydrolysis. Biotechnol Prog 15:804-816. https://doi.org/1 $0.1021 / \mathrm{bp} 9900864$

McMillan JD (1994) Pretreatment of lignocellulosic biomass. In: Himmel ME, Baker JO, Overend RP, et al. editors. Enzymatic Conversion of Biomass for Fuels Production. Proceeding of the 205th National Meeting of the American Chemical Society; American Chemical Society; Washington: P. 292-324.

Miller GL (1959) Use of dinitrosalicylic acid reagent for determination of reducing sugar. Anal Chem:426-428. https://doi.org/10.1021/ac60147a030

Phitsuwan P, Sakka K, Ratanakhanokchai K (2016) Structural changes and enzymatic response of Napier grass (Pennisetum purpureum ) stem induced by alkaline pretreatment. Bioresour Technol 218:247-256. https://doi.org/10.1 016/j.biortech.2016.06.089

Poornejad N, Karimi K, Behzad T (2013) Improvement of saccharification and ethanol production from rice straw by NMMO and [ BMIM ][ OAC ] pretreatments. Ind Crop Prod 41:408-413. https://doi.org/10.1016/j.indcrop.2 012.04 .059

Pu Y, Hu F, Huang F, Davison BH, Ragauskas AJ (2013) Assessing the molecular structure basis for biomass recalcitrance during dilute acid and hydrothermal pretreatments. Biotechnol Biofuels 6:1-13. https://doi.org/10.1186/1754-6 834-6-15

Rastogi M, Shrivastava S (2017) Recent advances in second generation bioethanol production: an insight to pretreatment, saccharification and fermentation processes. Renew Sustain Energy Rev 80:330-340. https://doi.org/10.1016/j. rser.2017.05.225

Ravindran R, Jaiswal AK (2016) A comprehensive review on pre-treatment strategy for lignocellulosic food industry waste : challenges and opportunities. Bioresour Technol 199:92-102. https://doi.org/10.1016/j. biortech.2015.07.106

Scherrer P (1918) Estimation of the size and internal structure of colloidal particles by means of röntgen. Nachr Ges Wiss Göttingen 2:98-100

Segal LG, Creely JJ, Martin AE, Conrad CM (1959) Empirical method for estimating the degree of crystallinity of native cellulose using the X-ray diffractometer. Tex Res J 29:786-794

Sluiter A, Hames B, Ruiz R, Scarlata C, Sluiter J, Templeton D, Crocker D (2008) Determination of structural carbohydrates and lignin in biomass. Lab Anal Proc 1617:1-6

Sun Y, Cheng J (2002) Hydrolysis of lignocellulosic materials for ethanol production : a review. Bioresour Technol 83(1):1-11. https://doi.org/10.1016/ S0960-8524(01)00212-7

Tsegaye B, Balomajumder C, Roy P (2018) Biodelignification and hydrolysis of rice straw by novel bacteria isolated from wood feeding termite. 3 Biotech 8(10):447

Tsegaye B, Balomajumder C, Roy P (2019a) Alkali pretreatment of wheat straw followed by microbial hydrolysis for bioethanol production. Environ Technol 40(9):1203-1211. https://doi.org/10.1080/09593330.2017.1418911

Tsegaye B, Balomajumder C, Roy P (2019b) Isolation and characterization of novel lignolytic, cellulolytic, and hemicellulolytic bacteria from wood-feeding termite Cryptotermes brevis. Inl Microbiol 22(1):29-39

Tsegaye B, Balomajumder C, Roy P (2019c) Optimization of microwave and $\mathrm{NaOH}$ pretreatments of wheat straw for enhancing biofuel yield. Energ Conver Manage 186:82-92

Tsegaye B, Balomajumder C, Roy P (2019d) Microbial delignification and hydrolysis of lignocellulose biomass to enhance biofuel production: an overview and future prospect. Bull Nat Res Centre 43(1):51. https://doi.org/1 0.1186/s42269-019-0094-x

Vandenbossche V, Brault J, Vilarem G, Hernández-Meléndez O, Vivaldo-Lima E, Hernández-Luna M et al (2014) A new lignocellulosic biomass deconstruction process combining thermo-mechano chemical action and bio-catalytic enzymatic hydrolysis in a twin-screw extruder. Ind Crop Prod 55:258-266. https://doi.org/10.1016/j.indcrop.2014.02.022

Wang M, Zhou D, Wang Y, Wei S, Yang W, Kuang M, Ma L, Fang D, Xu S, Du SK (2016) Bioethanol production from cotton stalk : a comparative study of various pretreatments. Fuel. 184:527-532. https://doi.org/10.1016/j.fuel.2016. 07.061

Yan J, Wei Z, Wang Q, He M, Li S, Irbis C (2015) Bioethanol production from sodium hydroxide / hydrogen peroxide- pretreated water hyacinth via simultaneous saccharification and fermentation with a newly isolated thermotolerant Kluyveromyces marxianu strain. Bioresour Technol 193:103-109. https://doi.org/10.1016/j.biortech.2015.06.069

Yang $H$, Yan R, Chen H, Lee DH, Liang DT, Zheng C (2006) Mechanism of palm oil waste pyrolysis in a packed bed. Energy Fuel 20(3):1321-1328. https://doi.org/10.1021/ef0600311

Zhang S, Keshwani DR, Xu Y, Hanna MA (2012) Alkali combined extrusion pretreatment of corn stover to enhance enzyme saccharification. Ind Crop Prod 37(1):352-357. https://doi.org/10.1016/j.indcrop.2011.12.001

Zhao C, Qiao X, Cao Y, Shao Q (2017) Application of hydrogen peroxide presoaking prior to ammonia fiber expansion pretreatment of energy crops. Fuel. 205:184-191. https://doi.org/10.1016/j.fuel.2017.05.073

Zhao C, Shao Q, Ma Z, Li B, Zhao X (2016) Physical and chemical characterizations of corn stalk resulting from hydrogen peroxide presoaking prior to ammonia fiber expansion pretreatment. Ind Crop Prod 83:86-93. https://doi.org/10.1016/j.indcrop.2015.12.018

Zhu S, Huang W, Huang W, Wang K, Chen Q, Wu Y (2015) Pretreatment of rice straw for ethanol production by a two-step process using dilute sulfuric acid and sulfomethylation reagent. Appl Energy 154:190-196. https://doi.org/10.1 016/j.apenergy.2015.05.008

\section{Publisher's Note}

Springer Nature remains neutral with regard to jurisdictional claims in published maps and institutional affiliations.

\section{Submit your manuscript to a SpringerOpen ${ }^{\circ}$ journal and benefit from:}

- Convenient online submission

- Rigorous peer review

- Open access: articles freely available online

- High visibility within the field

- Retaining the copyright to your article

Submit your next manuscript at $>$ springeropen.com 